\title{
Regional trade agreements as factor of expansion of foreign trade relations of Russia
}

\author{
Esina Yulia Leonidovna \\ Department of Accounting and Auditing \\ Bunin Yelets State University \\ Yelets, Russia
}

\author{
Stepanenkova Natalia Mikhailovna \\ Department of Accounting and Auditing \\ Bunin Yelets State University \\ Yelets, Russia
}

\author{
Agafonova Elena Evgenievna \\ Department of Accounting and Auditing \\ Bunin Yelets State University \\ Yelets, Russia
}

\begin{abstract}
The role of the WTO extenuation in regulation of international trade relations and prolonged stagnation of the world trade market compel individual states to conclude the alternative regional arrangements. Using of various kinds of preferences in the framework of these agreements and elimination of trade barriers is mutually beneficial for all the participants and have a favorable effect on the volumes of foreign trade. Regional trade agreements are an important tool for the development of world economic relations. In conditions of high geopolitical tension, the search for new formats of international cooperation is necessary to increase the competitiveness of the Russian Federation, to increase its share in world commodity markets and to overcome the consequences of imposed sanctions. In this regard, in order to reduce the influence of the political component, it is necessary to activate realization of international and foreign economic relations of the Russian Federation regions. The example is the foreign economic activity of the Lipetsk region, with its active expansion of international ties in terms of exporting products and attracting foreign investments. A great potential for expanding international trade operations has the Asian vector of economic cooperation. The conclusion of new regional trade agreements and further integration expansion of the Asia-Pacific region will attach an impulse to the economy of the Far Eastern regions, ensure the formation of a sustainable multilateral trading system, will create the possibility of using the geographical potential (seaports), and will promote the development of a joint transport and production infrastructure.
\end{abstract}

Keywords-international trade, regional trade agreements, economic cooperation, overcoming of sanctions restrictions, foreign economic relations of the regions of the Russian Federation, international integration.

\section{INTRODUCTION}

The modern globalized society is characterized by the presence of a large number of world economic ties and the rapid development of various international economic integration, primarily in trade. This is an urgent response to common challenges for individual countries, ensuring the protection of national interests, the consolidating efforts to achieve an economic growth.
In order to liberalize the international trade and regulate trade and political relations of various states, in 1947 the General Agreement on Tariffs and Trade (GATT) was concluded, on the basis of which the World Trade Organization (WTO) was established in 1995. Now 164 countries are WTO members, including most of the world recognized countries and the European Union. In 2016 the share of WTO member countries accounted for $98.2 \%$ of world trade, or 15.71 trillion USD.

However despite the obvious importance of the WTO, it began to lose its role in the development of international trade. In recent years, there was not any important document or a decision has been adopted in the WTO [1]. In addition, there was a slowdown in the world trade dynamics, and in 2016 the lowest growth rate since the financial crisis of 2008 was recorded, amounting to $1.3 \%$.

To overcome the prolonged stagnation of international trade relations within the WTO system, individual states use alternative regional arrangements that promote the development of mutual trade. Nowadays, the emphasis is moving to bilateral or multilateral trade agreements that create the most profitable regime between two or more countries. As of January 25,2018 , there were 284 regional trade agreements [2]. Trade within the European Union is $63 \%$ of the total volume of trade operations, in NAFTA, ASEAN, SADC and Southern Common Market, the internal volume of trade operations was respectively 50, 24, 18 and $14 \%$ [3]

Since January 1, 2015, the Russian Federation, Belarus and Kazakhstan, already members of the Customs Union, have formed a new economic unit - the EEU. The next day Armenia joined the organization, and in August of the same year Kyrgyzstan joined it. Candidates for joining the union are Tajikistan, Moldova, Uzbekistan, Mongolia, Turkmenistan, Iran, Turkey, Syria, Tunisia. On May 29, 2015, an agreement on a free trade zone between the EEU and Vietnam was signed. In addition to Vietnam, another 50 countries have expressed a desire to cooperate with the EEU. At the Russia-ASEAN summit, at the initiative of the Russian Federation, a proposal 
has been put forward for the «integration of integration» - the economic partnership of the EEU, ASEAN and the SCO. At the St. Petersburg International Economic Forum in June 2016, negotiations were started on concluding agreements between the EEU and China. In 2018 a conclusion of a cooperation agreement between the EEU and Iran is expected. The format of the EAEC has far-reaching prospects for development and is the core of continental cooperation.

Thus, regional models of trade integration are a relatively new initiative for the development of the global economy.

\section{PROBLEM STATEMENT}

For Russia, since 2014, geopolitical challenges have significantly increased. This is due to the high politicization of world trade and the expansion of foreign trade restrictions caused by using of anti-Russian sanctions.

Recently, the tendency to replace market competition with a political move or secret price collusion has been increasingly evident. It has already been repeatedly noted that the reason for the fluctuation in oil prices is not the result of the interaction between supply and demand, but the political agreement of individual states [4].

At the statement by the head of the International Monetary Fund, Christine Lagarde, trade wars are the greatest threat to the world economy at this stage [5]. The unpredictable behavior of individual players is destabilizing the situation on the international scene.

So CEO of the WTO Roberto Azevedo during the interview with the Financial Times said that blocking the appointment of new judges to consider international disputes in the WTO by the US president administration undermines the world trade system [6].

Therefore, in conditions of high geopolitical tension, expansion of formats for international cooperation is simply necessary to enhance Russia's competitiveness, increase its share in world commodity markets and overcome the consequences of imposed sanctions.

At the same time, it is necessary to take into account the capabilities of the partner countries, expanding the forms of interaction, first of all, with China - the largest and fastest growing market, and the peculiarities of Russia itself, involving the Russian Federation subjects in participating in the international trade.

\section{RESEARCH QUESTIONS}

The research questions were reflected in the works of leading Russian and foreign scientists. The role of international trade as a driving force for the world and national economies and as an effective tool for solving numerous global problems is disclosed in the works of Avdokushin E.F. and Kudryashova I.A. [7].

The authors note that, on the one hand, international trade is a reliable tool for cost-effective use of resources. On the other hand, the desire to reduce production costs leads to the location of pollution-related industries in countries with not strict environmental control that exacerbates environmental problems.

American economist B. Balassa in his work «The Theory of Economic Integration», published in 1961, proposed the following classification of stages in the field of integration:

1) a free trade area;

2) the customs union;

3) the common market;

4) the economic union;

5) full economic integration [8].

Portansky A.P. notes that the opinions of international experts on the issue of the opposition or complementarity of existing trends in the further progress of the multilateral trading system (MTS) and the development of regionalism diverge.

The author believes that regional trade agreements should complement the MTS. Obviously, from the point of view of trade policy, the picture of the world could be considered ideal if trade relations between all countries would be regulated by only one universal structure - such as the WTO. But the WTO is an institution that emerged only at the end of the twentieth century. Much earlier, in the period of strengthening the colonial empires, the internationalization of economic activity naturally led to the formation of regional economic groupings, that was a completely objective process [9].

N.A. Vasilyeva and M.L. Lagutina, analyzing the prospects for the development of the EEU, believe that in the context of the WTO crisis, interaction in the format of a free trade zone is the best form of cooperation for many countries and associations, including for the EEU [10]. A similar opinion is shared by other researchers (Kosov Y.V, Frolov V.E., Lapenko M.V., etc.).

A number of authors widely discuss the current situation of the Russian Federation in the world market, consider the most significant changes in the structure of Russian exports and the advantages of domestic goods in the markets of Africa, Asia and the CIS [11]. In other works, new geopolitical challenges in foreign trade activity and peculiarities of foreign economic relations of Russian regions are considered. It is noted that the regions play an increasingly important role in the development of Russia's foreign trade activities [1].

The questions concerning the consequences of Russia's accession to the WTO are examined in the works of a number of researchers [12]. It is noted that the Russian Federation legislation has been adapted in accordance with WTO rules. In addition, a decision to reduce import tariffs, fix export duties was made, the protection of intellectual property rights was provided, and sanitary standards and technical regulations were reviewed.

Popkova E.G. and Sukhodolov Ya.A. in their scientific works, consider Russia's national interests and priorities, the level of foreign economic institutions development, the position of the national economy in the context of the «turn to the East» strategy, and justify the need to intensify a cooperation with the developing countries of Asia, primarily with China [13, 14]. 
The construction of the foreign trade model of the Russian Federation subjects with China, as well as the assessment of the impact of Chinese investment on trade relations between Russia and China were also undertaken by Malkina M.Yu., Gorbunova ML, Ovchinnikov V.N. [15]. It was concluded that Chinese investors prefer to trade with nearby and highly profitable (resource-rich) subjects of the Russian Federation.

In the prevailing conditions, for Russia, experiencing socioeconomic and foreign policy restrictions, a reliable, powerful, engaged and motivated partner for long-term cooperation is needed. Dynamic development in the XXI century of Asian countries, primarily China, as well as the productive RussianChinese interaction and the current political, trade and economic agreements between the two countries open new prospects for changing the format of trade cooperation between Russia and China.

In this process, in the opinion of Y.A. Sukhodulov, the leading role can be played by those regions of Russia that have a great development potential and for which China is the leading foreign trade partner. Thus, according to the author, changing the format of foreign trade cooperation between Russia and China in the context of the fast-growing Asian vector of the world economy, involving the regions of Russia in this process and the formation of a national innovative economy are contributing to the solution of the most important national economic task of increasing the significance of our country in the world community [16].

\section{PURPOSE OF THE STUDY}

Loss of global dominance of WTO rules and the active promotion of the protectionist measures of a number of counties give a powerful impetus to the emergence and development of regional integration unions and to the conclusion of new formats of regional trade agreements. In this regard, the aim of study is to identify possible directions and forms of regional trade agreements, taking into account the current state and specifics of Russia's trade relations.

International trade relations of Russia are formed under the influence of both external factors - a complex geopolitical situation and the imposition of sanctions, and internal - sectoral and territorial disparities of the national economy. The influence of these factors determined the dynamics of the main indicators of Russia's foreign trade. (fig. 1)

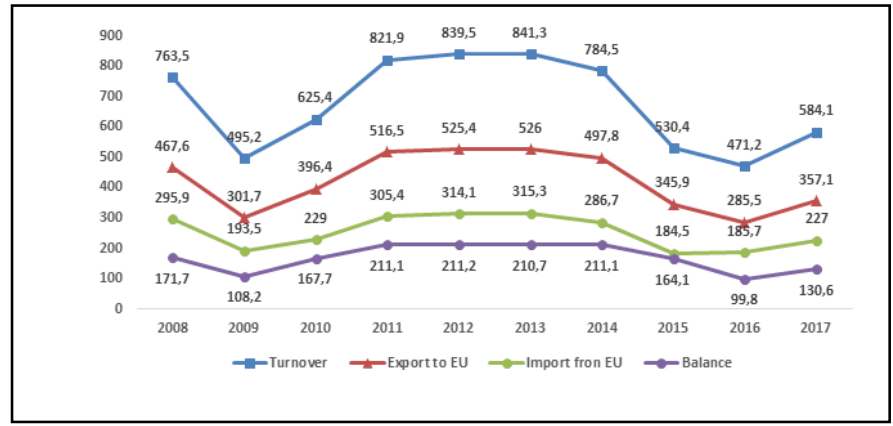

Fig. 1. The main indicators of Russia's foreign trade, bill. US doll

As can be seen, anti-Russian sanctions have caused a decline in the volume of foreign trade in all key indicators. Only in 2017, Russia's foreign trade, for the first time in four years, demonstrated growth.

The largest trading partner of Russia is traditionally the European Union, which accounted for $42.7 \%$ of the foreign trade turnover in 2017. In addition, Russia actively cooperates with other countries of the far abroad. So, in 2017, the share in the foreign trade turnover of the countries of the Asia-Pacific Cooperation amounted to $32 \%$, the BRICS countries - $18 \%$, while the share of the states-participants of the Commonwealth of Independent States (CIS) accounted for 12\%, the member states of the EEU - 9\%, the OPEC countries - 3\%.

Among the individual countries the main trading partners of Russia in 2017 were China $-15 \%$ of the foreign trade turnover, Germany $-9 \%$, the Netherlands - 7\%, Belarus - 5\%, Italy - 4\%, the USA - 4\%, Turkey - 4\%, the Republic of Korea - 3\%, Kazakhstan - 3\%, Ukraine - 2\%

An acute problem of Russia's foreign trade is the low share in world exports (fig. 2).

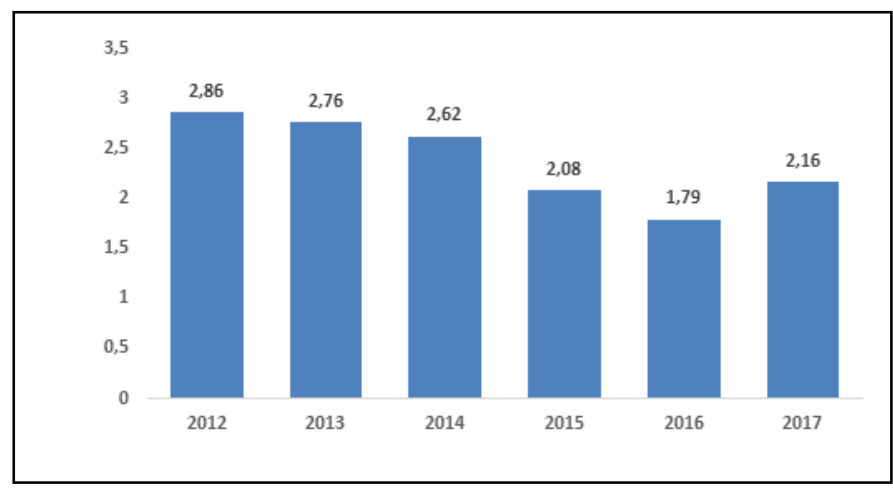

Fig. 1. The share of Russia in world exports

\section{FINDINGS}

Despite political disagreements, imposed sanctions restrictions and countermeasures taken in response, the European Union remains a priority direction for the development of trade relations for Russia. Restrictions on the Russian market force European countries to seek new markets, change the structure of the export market in favor of Turkey, India, Brazil, the Arab Emirates, South Korea and Saudi Arabia. At the same time, contrary to the sanctions policy, the trade turnover between the EU and the Russian Federation began to recover. As before, the predominant share of European exports to Russia consists of production equipment $(22 \%)$, machinery $(11 \%)$, electronic equipment $(9 \%)$, medicines $(9 \%)$ and agricultural products (7\%). Russia is interested in its western partner as a supplier of fossil fuels, which accounts for $67 \%$ of Russian exports to the EU. However, the volume of supplies from the EU countries amounted to only $60.6 \%$ of the pre-crisis level by the end of 2016, and the volume of exports from the Russian Federation - 57.3\% (table I). However, the pace of recovery in trade turnover in 2017 looks quite encouraging, but there is a noticeable growth in Russia's trade surplus. 
TABLE I.

TRADE OF RUSSIA WITH THE EU IN 2013-2017. (IN BILLIONS OF EURO) A

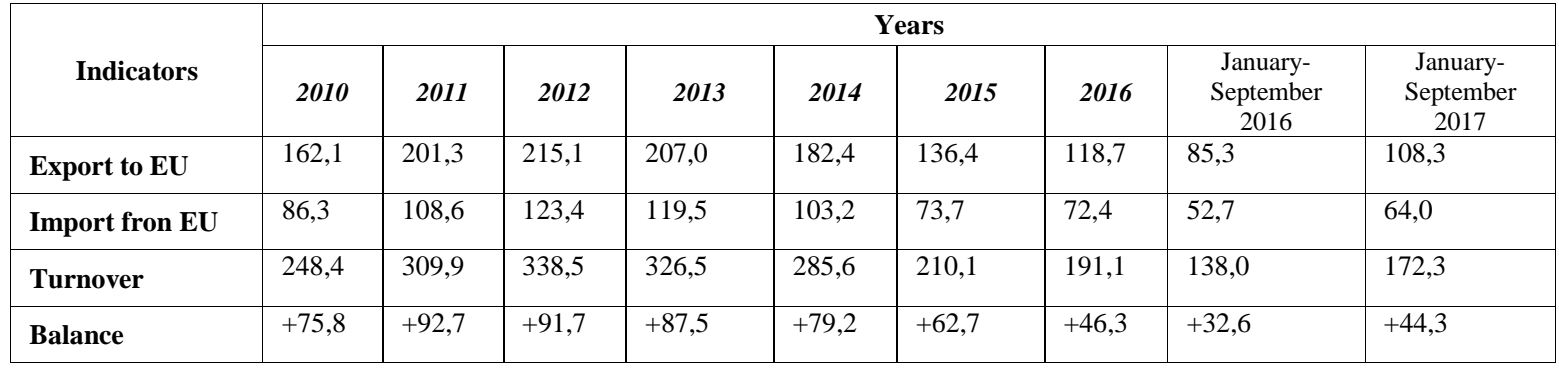

http://ec.europa.eu/eurostat/statistics-explained/index.php/Main_Page

At the present stage, for Russia, experiencing socioeconomic and foreign policy restrictions, a reliable, powerful, interested and motivated partner for long-term cooperation is needed. The dynamic development of the Asian countries, primarily China, in the twenty-first century, as well as the productive Russian-Chinese interaction and the current political, trade and economic agreements between the two countries, open new prospects for changing the format of trade cooperation between Russia and China. According to Deputy Prime Minister of the Russian Federation Dmitry Rogozin, in the first half of 2017, trade between China and Russia has already exceeded $\$ 38$ billion.

President of the Russian Federation Vladimir Putin in his article «XXV APEC summit in Danang: together with prosperity and harmonious development», published on the Kremlin's official website in November 2017, notes that Russia today sees practical interest in the free trade zone in the AsiaPacific region and the opportunity to strengthen positions in the dynamically growing markets of the region. And also focuses attention on the fact that «the countries strive to interact on the basis of the principles of consensus and voluntariness, mutual respect and readiness for compromise, regardless of political conjuncture» [17].

The free trade zone is the most beneficial form of cooperation for countries with an intensive real sector of the economy, where China enters an unconditional leader. In his report at the Moscow Economic Forum in 2018, the plenipotentiary minister, trade and economic adviser to the Chinese Embassy in Russia, Li Jingyuan, said that the agreement on trade and economic cooperation between the EEU and China is planned to be signed in the first half of 2018.

In October 2016, the free trade zone with Vietnam began, the agreement for which was signed back in March 2015 and marked the exit of the processes of Eurasian integration beyond the post-Soviet space. According to the estimates of the Eurasian Economic Commission, the creation of a such free trade zone between countries can increase the trade turnover between partners from the current level of 4 billion US dollars to 8 - 10 billion US dollars in a few years after the entry into force of the Agreement.

Another step towards expanding international cooperation in the framework of regional trade agreements with Vietnam, which has recently come to the forefront of the list of the largest trading partners of the Russian Federation in South-East Asia, is the signing of a protocol that is part of a package of agreements on the establishment of a free trade zone between EEU and Vietnam, the implementation of which in practice will allow Russian companies to take advantage of preferential terms for the import and for the assembly of domestic vehicles in Vietnam. The protocol provides for an increase in the level of assembly localization to $35 \%$ in the period until 2020 and to $45 \%$ by 2026 .

Active work is under way to expand trade ties with Iran, the possibility of concluding an interim agreement leading to the formation of the Iran-EAPC free trade zone as early as May 2018 is being considered. In accordance with the agreement, import duties will be reduced by the minimum number of goods - about 200 tariff lines on both sides. If the preferential trade is recognized as effective, then a transition to a full-format free trade zone is possible.

In the conditions of increasing politicization of foreign trade activities and a departure from the implementation of WTO rules by all countries, there is a process of developing trade agreements within the economic blocks and associations (NAFTA, APEC, SCO, EEU, etc.). In this regard, in order to reduce the influence of the political component, it is necessary to increase participation in the implementation of international and foreign economic relations of the regions of the Russian Federation. An example of this is the foreign economic activity of the Lipetsk region. In 2017, the enterprises and organizations of the Lipetsk region actively pursued trade activities with 99 countries of the world, and the geography is actively expanding, over the last year agreements were concluded with 8 more countries. The foreign trade turnover of the Lipetsk region in 2017 as compared to the previous year increased by $42.0 \%$ and amounted to 5621.6 million US dollars.

The trade surplus was $\$ 3,054.0$ million. The volume of exports of goods from the Lipetsk region exceeds the volume of imports to the region 3.4 times. The region actively cooperates with the EEU member states. The increase in the export of Lipetsk goods to Belarus was 1.4 times, to Kazakhstan - 2.5 times, Uzbekistan - 4.4 times. The main trading partners of the Lipetsk region in 2017 were: Turkey - 23.7\%, Mexico $18.1 \%$, Belgium - $16.6 \%$, Germany and Denmark - 5.6\%, 
Belarus $4.3 \%$, China $3.4 \%$, the USA $2.9 \%$, Ukraine $-2.8 \%$, the Netherlands - 2.3\% [18].

The predominant share of exported products $(91.3 \%)$ is made by ferrous metallurgy of Public Corporation «NLMK» that is traditional for the region. Due to this category, the main growth of export supplies occurred (by $42 \%$ ). But the region is actively diversifying its production activities, that allowed 50\% increase in the export of food products and $72 \%$ increase in machinery production. As a result, food products (cereals, sunflower oil, mineral water) accounted for $4 \%$ of the export structure, and machine-building (washing machines, refrigerators and freezers) accounted for $3 \%$. The main countries that buy the region's products are Turkey $(31 \%)$, Mexico (23\%), Belgium (21\%), Denmark (7\%), Belarus (4\%), USA (3\%).

In comparison with the previous year, the import deliveries increased by $40 \%$, amounting to $\$ 1,244$ million in 2017 . The main import increase is associated with the growth in purchases of machinery and equipment by $45 \%$ for the implementation of investment projects in the region. Simultaneously, the adopted policy of import substitution allowed to reduce the import of food products by $11 \%$. In the commodity structure of the region's imports, $50.2 \%$ are the machine-building products, $15.1 \%$ are metals and the metal products, $13.2 \%$ are the chemical products, and $8 \%$ are the mineral products. The region actively promotes its interests within the framework of the 5th meeting of the Russian-Japanese dialogue on investment in small and medium-sized businesses, at the VII RussianSwedish Economic Forum, at the 10th Eurasian Economic Forum and other venues. Following the results of 2017 Lipetsk region was among the top three leaders of the Central Federal District for attracting capital and the volume of investments was twice the size of the regional budget. The majority of foreign investments are made by residents of the SEZ «Lipetsk». At present, there are 52 companies with the volume of declared investments of 173.8 billion rubles. The volume of products produced in the territory of the SEZ «Lipetsk» amounted to 61.5 billion rubles. In 2018 the region, despite the strengthening of the sanctions policy, expects to conclude agreements with foreign companies for another 12 billion rubles. Negotiations are in progress with the American companies: Air Products (industrial gas production), Cargill (food production) and Honeywell (electronic control and automation systems), the $\mathrm{NCH}$ Capital investment fund (real estate and agrarian sphere), the international Bayer concern (chemical and pharmaceutical production), the Swiss company Dega Group (development) [19].

Thus, certain regions of the Russian Federation contribute to the development of world economic relations and promote overcoming political differences.

\section{CONCLUSION}

In the context of the decline in the role of the WTO in regulating international trade relations and the prolonged stagnation in world trade, some states are increasingly using alternative regional arrangements. The use of various kinds of preferences within the framework of these agreements and elimination of trade barriers is mutually beneficial for all participants and has a favorable effect on the volume of foreign trade and the state of the country's economy. At the same time, not only goods produced, but also knowledge, experience and human capital are exchanged between participants in regional trade agreements (RTAs). In the context of aggravated geopolitical tensions, the fact that not individual countries, but the trade blocs of countries and integration associations are competing more clearly, makes it easier to come up with a common position. In this regard, Russia's conclusion of RTAs with other countries or trade blocs is becoming one of the priorities of the national foreign policy and a key instrument for the development of international trade. Currently, Russia has 13 existing regional trade agreements, concluded primarily with the countries of the former USSR and the CIS. Conclusion of new RTAs and further expansion of integration processes will allow developing individual regions of the country (for example, in case of further integration into the Asia-Pacific region, this will be the Far Eastern regions), will create a stable multilateral trading system, will create an opportunity to use the best practices and experience of participants in foreign trade agreements

\section{References}

[1] A.F. Linetsky, A.G. Tarasov, V.E. Kovalev. "The role of regions in Russia's foreign trade activity in the conditions of new geopolitical challenges Economikaregiona" [The Economy of the Region], 2017, vol. 13, no. 3, pp. 827-838 (in Russian).

[2] WTO Regional trade agreements. Available at: https://www.wto.org/english/tratop_e/region_e/region_e.htm

[3] World trade and GDP growth in 2016 and early 2017. Available at: https://www.wto.org/english/res_e/statis_e/wts2017_e/WTO_Chapter_0 3_e.pdf

[4] A. Ghoshray, B. Johnson, 'Trends in world energy prices", Energy Economics, 2010, vol. 32, pp. 1147-1156.

[5] Jim Randl «The head of the IMF said about the danger of the «collapse» of world trade», in press

[6] «The head of the WTO: Trump can undermine the world's trading system» Availableat: https://www.eurointegration.com.ua/rus/news/2017/10/2/7071765/

[7] E.F. Avdokushin, I.A. Kudryashova "Some trends in Russian food product export in the meaning of the international trade development" Foods and Raw Materials, 2016, v. 4, no. 2, pp. 148-156.

[8] A. Balassa Bela The Theory of economic integration. Homewood : R.D. Irwin, 1961

[9] A.P. Portansky "World tendency of regionalism and integration in the CIS”, Rossiyskiyvneshneekonomicheskiyvestnik, Russian foreign economic bulletin, 2011, no. 11, pp. 8-17

[10] N.A. Vasilyeva, M.L. Lagutina, "Eurasian Economic Union in the Transformation of the International Trade System", Eurasian Law Journal, 2016, no. 1, pp. 29-31

[11] I. Benesova, M. Maitah, L. Smutka, K. Tomsik, N. Ishchukova "Perspectives of the Russian agricultural exports interms of comparative advantage", Agric, Econ, Czech, 2017, 63, pp. 318-330.

[12] V. Gnevko, N. Shahina, S. Kirsanov "Implications of the Russian Federation's accession to the WTO", Tekhnicheskayainzheneriya Procedia Engineering, 2016, vol.165, pp. 1039 - 1045

[13] E. Popkova, Y. Sukhodolov "Role and Meaning of Foreign Trade Cooperation in the Globalizing World Through the Example of Russia and China", Vkladekonomiki, Contributions of economics, 2017, pp. 4773 
[14] E.G. Popkova, E.G.Popkova, Y.A.Sukhodolov "Foreign trade as a factor of economic growth. Russian-chinese foreign trade cooperation",.Cham Springer International Publishing, 2017, pp. 148.

[15] M.Malkina, V.Ovchinnikov, M.Gorbunova. "Interaction between China and the Russian regions in the area of direct investment and foreign trade', Terra economicus. 2017, vol. 15 (2), pp. 93-108.

[16] Y.A. Sukhodolov "Russian-Chinese foreign trade cooperation as a factor in the development of the Russian economy" [the abstract of dissertation of the candidate of economic sciences, Rostov-na-Donu, 2016, $50 \mathrm{p}]$.

[17] Vladimir Putin's article «XXV APEC Summit in Danang: Together for the prosperity and harmonious development». Available at: http://kremlin.ru/events/president/news/56023

[18] The general results of foreign trade of the Lipetsk region for 2017. Central Customs Board, Available at: http://ctu.customs.ru/index.php?option=com_content\&view=article\&id= 13758:-2017-\&catid=47:tob-cat

[19] The first Internet newspaper of Lipetsk, Available at http://lipetsknews.ru/articles/biznes/140-mlrd-rubley-investiciy-privelilipeckuyu-oblast-v-troyku-liderov-v-cfo-po 